\title{
Investigation of a Shallow Aquifer Near the Fenton Hill Hot Dry Rock Site Using DC Resistivity
}

\author{
Christopher F. Pearson
}

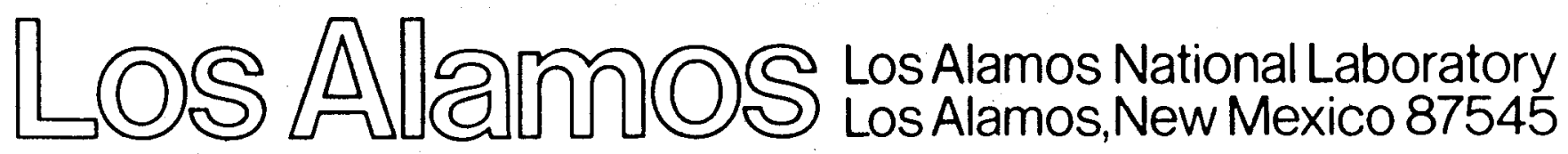




\section{DISCLAIMER}

This report was prepared as an account of work sponsored by an agency of the United States Government. Neither the United States Government nor any agency Thereof, nor any of their employees, makes any warranty, express or implied, or assumes any legal liability or responsibility for the accuracy, completeness, or usefulness of any information, apparatus, product, or process disclosed, or represents that its use would not infringe privately owned rights. Reference herein to any specific commercial product, process, or service by trade name, trademark, manufacturer, or otherwise does not necessarily constitute or imply its endorsement, recommendation, or favoring by the United States Government or any agency thereof. The views and opinions of authors expressed herein do not necessarily state or reflect those of the United States Government or any agency thereof. 


\section{DISCLAIMER}

Portions of this document may be illegible in electronic image products. Images are produced from the best available original document. 
Dis book was prepared as an accoun of DISCLAIMER

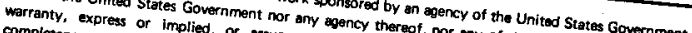

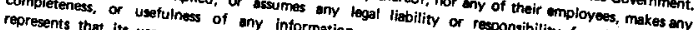

commercial product, use would not infringe privately apparatus, product, of procos the eccuracy,

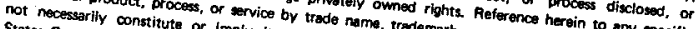

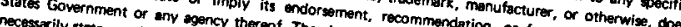

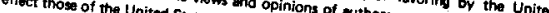

.

INVESTIGATION OF A SHALLOW AQUIFER NEAR THE FENTON HILL

HOT ORY ROCK SITE USING DC RESISTIVITY

by

Christopher F. Pearson

ABSTRACT

We investigated a shallow aquifer in the base of the Tertiary volcanic sequence using a series of 9 DC Schlumberger soundings taken within $10 \mathrm{~km}$ of the Fenton Hill hot dry rock geothermal site. The aquifer dips to the southwest following the top of the Abo formation, which acts as an aquiclude. Depth increases from $130 \mathrm{~m}$ in the eastern part of the study area to $260 \mathrm{im}$ at $1.5 \mathrm{~km}$ west of the Fenton $\mathrm{Hill}$ site. Aquifer resistivities varied from $13 \Omega-m$ to $126 \Omega-m$, which could be caused by variable permeability in the aquifer. Using results from empirical studies we estimated permeabtitities ranging from 40 darcies to less than 0.3 darcies with the highest values occurring nearest to the Fenton Hill site.

\section{INTRODUCTION}

This report describes geophysical investigations of a shallow ground-water aquifer that supplies domestic water for Los Alamos National Laboratory's hot dry rock (HDR) demonstration site near Fenton Hill, New Mexico. This survey is part of a larger hydrologic investigation ${ }^{1}$ to determine if the Fenton Hill water supply aquifer can provide significantly greater quantities of water for fracturing and heat-extraction operations in the much deeper Phase II geothermal reservoir. The major purpose of the geophysical survey was to locate and contour the top of the aquifer near Fenton $\mathrm{Hill}$. We also hoped to estimate aquifer permeabilities because this relates to the amount of water that can be removed from the aquifer.

During this study, we used direct current (DC) resistivity with an expanding Schlumberger electrode configuration as our primary geophysical technique. This type of resistivity survey, which is commonly used in ground-water investigations,? uses surface electrical measurements to estimate subsurface resistivities. Because porous rocks saturated with water have much lower resistivities than dry rocks, the water table can usually be detected as a low resistivity layer.

The location of the 19 Schlumberger soundings used are shown in Fig. 1. Five of these soundings were conducted by Los Alamos staff and the other 14 were provided by Jiracek. ${ }^{3}$ All the soundings were within $5 \mathrm{~km}$ of Fenton $\mathrm{Hill}$ and, of these, 9 independently detected the aquifer. our two major conclusions are (1) the aquifer dips gradually to the southwest with depths ranging from $130 \mathrm{~m}$ near Fenton $\mathrm{Hill}$ to greater than $200 \mathrm{~m}$, $3 \mathrm{~km}$ to the west and (2) our estimates of aquifer resistivity vary significantly suggesting that the aquifer has variable porosity.

GEOLOGY

The survey area is located slightly to the west of the Valles caldera, a huge Quaternary volcanic center in central New Mexico. The area includes a portion of the topographic rim of the Caldera and recently dissected volcanic plateaus and mesas. Most of the western part of the study 


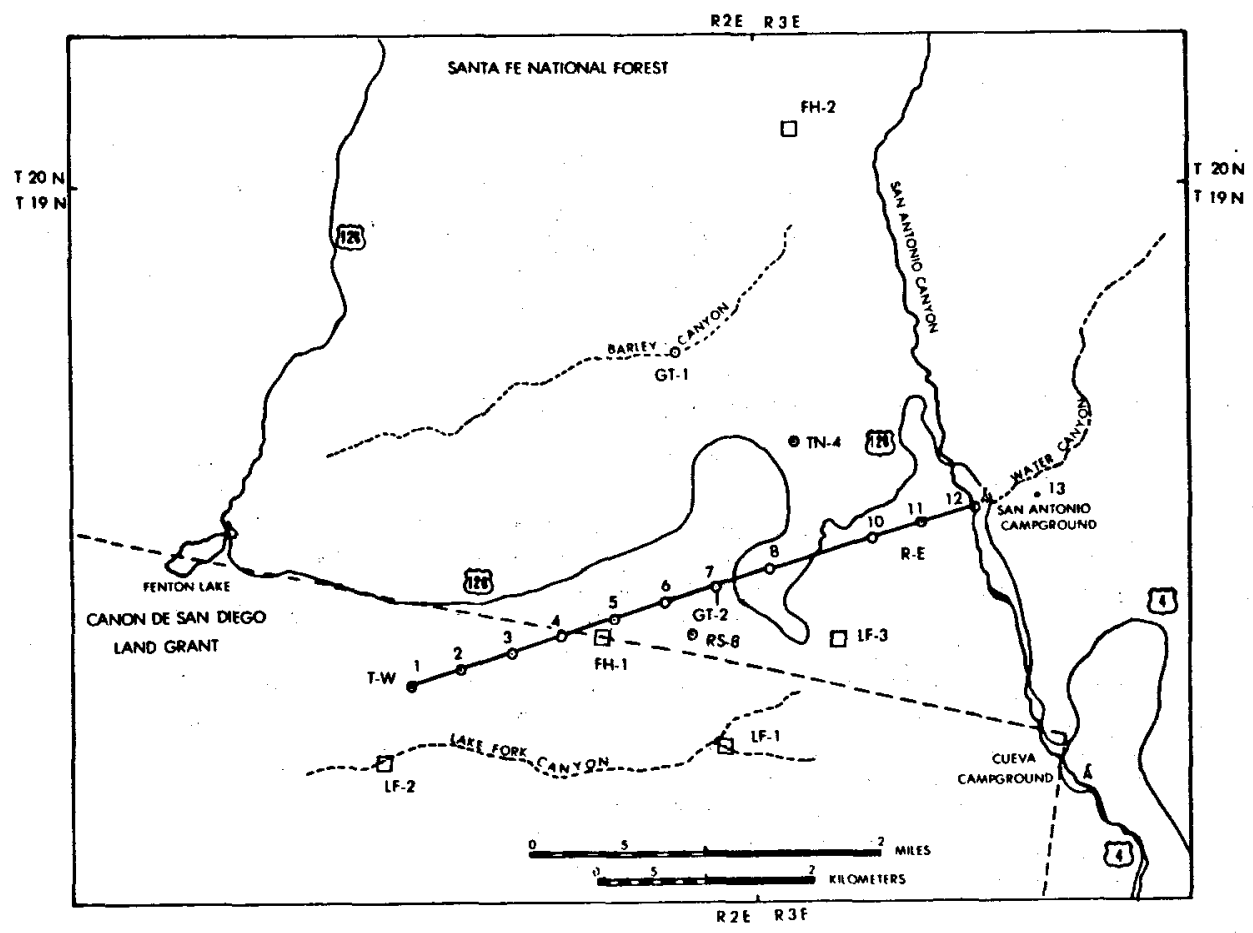

Fig. 1 .

Survey area in the Jemez Mountains near the Fenton Hill HOR geothermal site showing the locations of the Schlumberger soundings.

area is covered by a thick welded ash flow deposit; called the Bandelier Tuff, which overlies the other thin volcanic layers (The Paliza Canyon Formation and the Abiquiu Tuff) as well as the Permian rocks of the Abo formation. The Permian sedimentary rocks, stripped of volcanic cover, outcrop in the San Antonio Creek valley. Whereas the sedimentary and volcanic rocks are generally flat lying, Smith, Bailey, and Ross ${ }^{4}$ map one normal fault in the eastern part of the study area. An expanded version of their map (for the area near the HDR geothermal site) is shown in Fig. 2. In addition, Kintzinger, Reynolds, West, and Suhr ${ }^{5}$ detected several other buried faults near the HDR site during a high-resolution seismic reflection survey.

Drink ing water for the HDR site comes from a shallow (130-m depth) perched aquifer in the Abiquiu Tuff near the Fenton Hill site, as described by Purtymun, West, and Pettitt ${ }^{6}$. The saturated zones overlay the top of the Abo formation, a relatively low-permeability sedimentary sequence, which acts as an aquiclude. This aquifer is overlain by a thick (107 $\mathrm{m}$ at GT-2) layer of Bandelier Tuff and a much thinner layer of volcanic breccia, which is on $1 y 20 \mathrm{~m}$ thick at GT-2. No water saturated zones were found in the overlying volcanics while drilling GT-2. 6

Table $I$ is a compilation of a general description of the lithology under the HDR geothermal site. This aquifer is thought to dip gradually to the southwest, closely following the top of the Abo shale. It also causes a variety of springs and seeps that occur when nearby canyons intersect the Abiquiu Tuff. A few kilometers west of Fenton $\mathrm{Hill}$, the aquifer is apparently truncated by a north-south trending normal fault that uplifts the underlying paleozoic sediments by as much as $120 \mathrm{~m}$. There is no evidence that the aquifer extends west of San Antonio Canyon.

METHOD

We studied the aquifer using a OC resistivity technique known as electric drilling or 

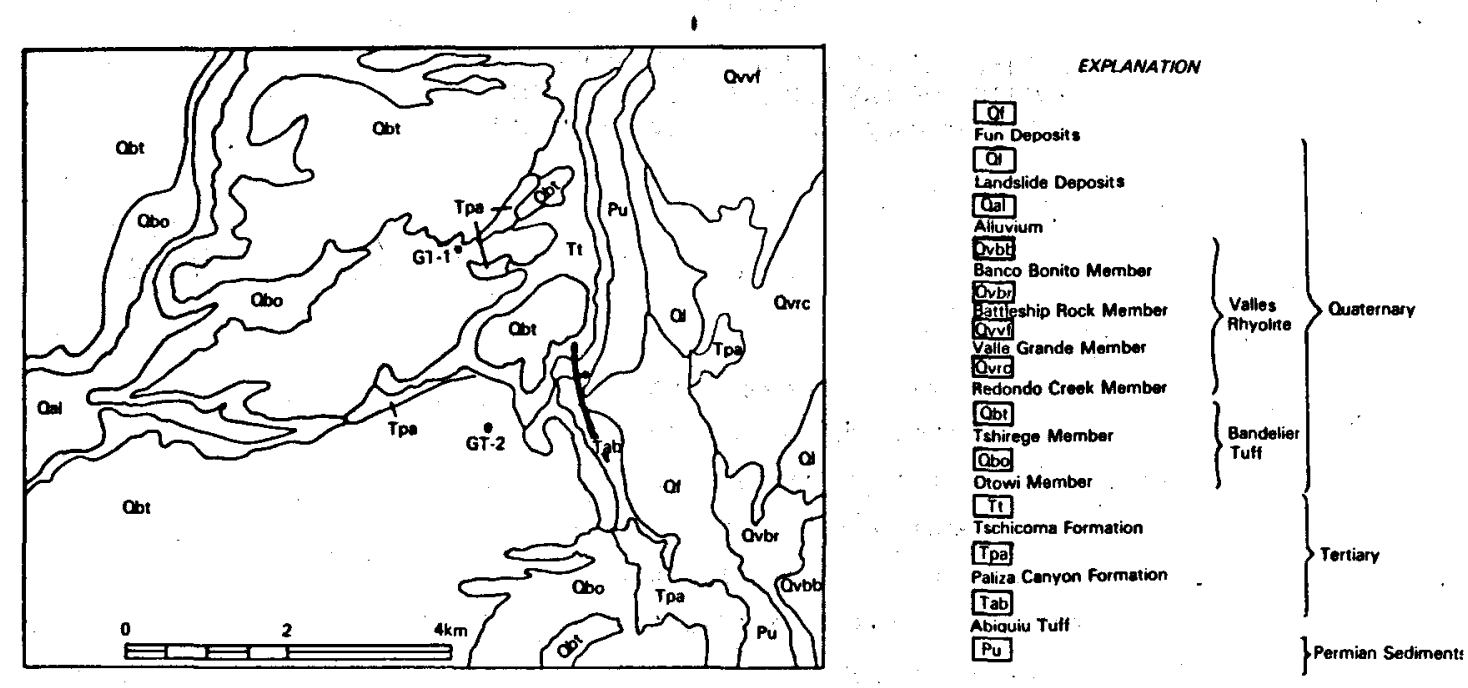

Fig. 2.

Geologic map near the Fenton Hill HDR site after Smith, Bailey, and Ross. 4

vertical electrical sounding with a Schlumberger electrode configuration. This technique requires four electrodes in a colinear array. When making a measurement, we passed a DC current between two of the electrodes (the current electrode pair) while measuring the resulting voltage drop between the other two electrodes. In the Schlumberger electrode configuration, shown schematicaliy in Fig. 3, both electrode pairs are placed symmetrically about the centerpoint and the distance between potential electrodes is much less than the distance between the current electrodes $(<25 \%)$.

During an electric drilling or vertical electrical sounding survey (so named because the technique measures subsurface resistivity as a function of depth, much like an electric log from a drill hole), the separation between the current electrodes is increased between each measurement. The separation between the potential electrodes only increases when the voltage drop becomes too small to measure accurately. Each time the electrodes were moved we recorded the electric current passing between the current electrodes and the voltage drop between the potential electrode pair. Using these two values plus the potential and current electrode spacings, $a$ and $b$ in $F 1 g .3$, we calculated the apparent resistivity after removing the effect of electrode spacing. Physically, the effective resistivity would be the true earth resistivity if the earth were electrically uniform and isotropic. Because this is never the case, the apparent resistivity represents a value averaged over many near-surface layers, each having different electrical properties. As the electrode spacing is increased, this normalized resistivity is affected by beds at increasing depths beneath the surface. Thus the apparent resistivity is a slowly varying function of electrode separation, increasing if the subsurface resistivity increases with depth and decreasing if the resistivity decreases. The apparent resistivity vs electrode separation curve or the Vertical Electrical Sounding (VES) curve contains information on the electrical properties of the subsurface and, if the survey is carried out over a horizontally layered structure, can be inverted to give an estimate of the subsurface resistivity as a function of depth (the geoelectric section). A more complete description of equipment and field procedures is found in Appendix A.

We calculated the apparent resistivity (o $\left.\rho_{a}\right)$ using the following formula?

$$
\frac{\Delta V \pi}{I}\left(\frac{a^{2}}{b}-\frac{b}{4}\right)=\rho_{a}
$$

where $a$ is half the distance between the current electrodes, $b$ is the distance between the potential electrodes (see Fig. 3) and $\Delta V$. and I are the measured potential difference and current. From 
TABLE I,

FIELO GEOLOGIC LOG OF TEST HOLE GT-2

ELEVATION OF LAND SURFACE $8690 \mathrm{FT}(2648.7 \mathrm{~m})$

After Purtymun, West, and Pettitt6

Depth to

Bottom

Bandelier Tuff

Tuff, dark gray, moderately welded to

welded, rhyolitic crystal and crystal

fragments of quartz and sanidine, lithic

fragments of pumice, rhyolite, and latite

in ash matrix. Pumice, light gray with

lithic fragments of light to dark gray

rhyolite. Moderately welded tuff 0 to

$110 \mathrm{ft}$; pumice 110 to $250 \mathrm{ft}$; welded tuff

250 to $295 \mathrm{ft}$; moderately welded tuff 295

to $325 \mathrm{ft}$; welded tuff 325 to $350 \mathrm{ft}$.

106.7

106.7

Paliza Canyon Formation

Andesites and basaltic andesite breccia,

dark gray, with interbedded sands and

gravels.

121.9

Abiquiu Tuff

Sandstone, light gray tuffaceous, friable,

with angular basalt in upper part of section,

crystal fragments of quartz, sanidine, and

chalcedony; lithic fragments of rhyolite and

quartzite in tuffaceous sand matrix.

15.2

137.1

Abo Formation

Shale, siltstone, and fine-grained sandstone, brownish-red to dark red, with lenses of

white to gray shale.

$237.7 \quad 374.9$

an apparent resistivity vs electrode separation curve we can infer the resistivity as a function of depth.

We interpreted the data using a computer program developed by $20 h d y^{8}$ for the automatic interpretation of Schlumberger sounding curves. Because this program takes data at a logarithmic spacing of six points per decade, we had to use interpolated values as input. We interpolated the necessary values by plotting electrode separation vs apparent resistivity in log-log repre- sentation, drawing a smooth curve through the data and digitizing six points per decade. This procedure allowed us to smooth the curve and remove the perturbations due to variable near-surface resistivities, extraneous telluric currents, and reading errors before the data were analyzed. The interpretation program first assumes a model where the number of points equals the total number of points available. This model, which usually matches the observations very well, is needlessly complex, so the program simplifies the model by 


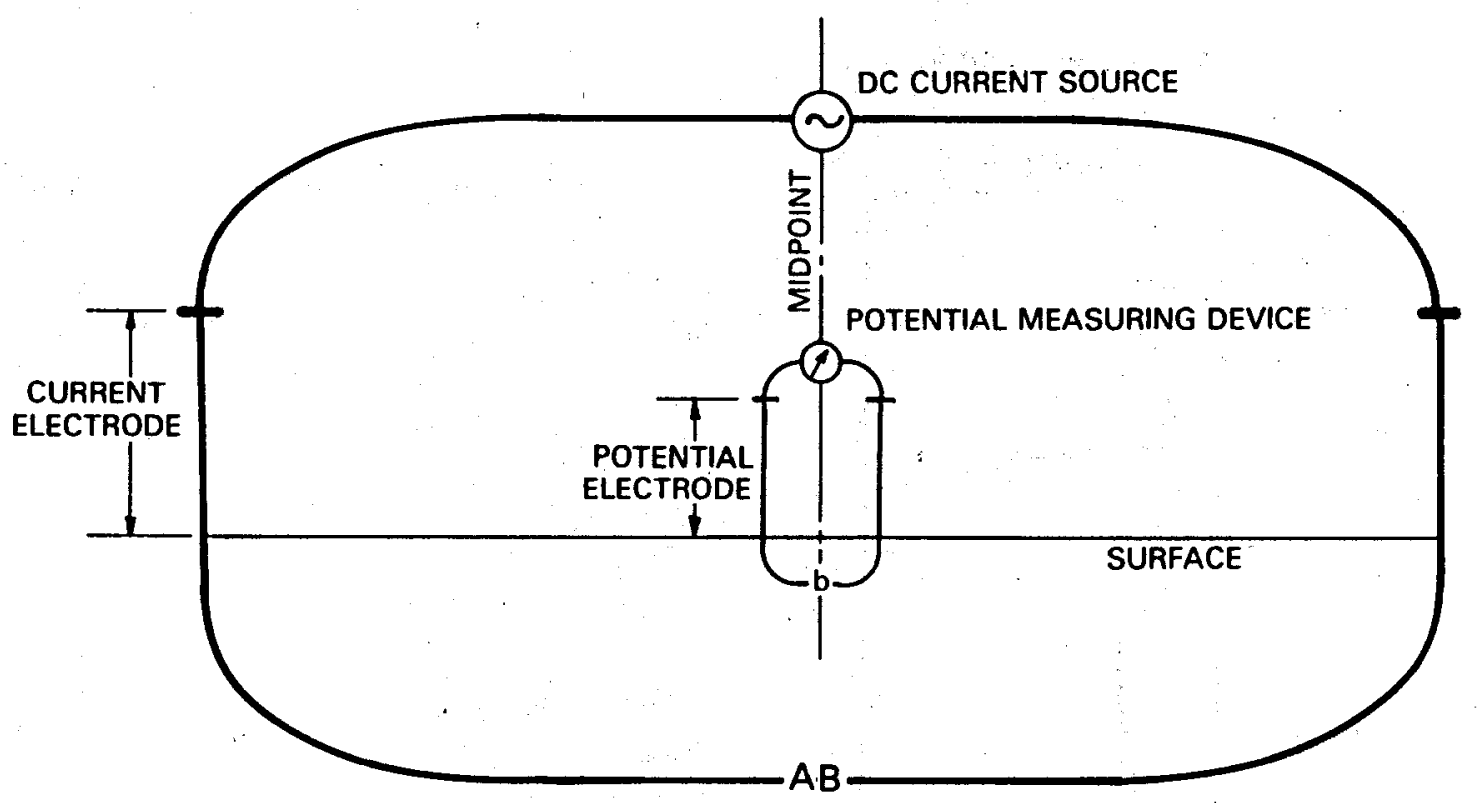

\section{$A B=$ CURRENT ELECTRODE SPACING \\ $b=$ POTENTIAL ELECTRODE SPACING}

Fig. 3.

Schematic diagram of the Schlumberger electrode configurations.

successively reducing the number of layers. We always chose the simplest model that fit the data within a 10 error. Interpretations of the sounding curves are given in Appendix B. Sounding curves for the 19 Schlumberger soundings along with the theoretical fit are shown in Appendix $\mathrm{C}$.

$D C$ resistivity measurements can only measure the earth resistivity as a function of depth beneath the surface. However, if we know the geology and the approximate resistivities of formations likely to be in the area, we can use $D C$ resistivity as a tool to map subsurface geology. In this survey we fortunately had a detailed lithologic $\log$ and a resistivity $\log$ from GT-2 (Fig. 4), one of two wells that make up the HDR geothermal system at Fenton Hill. Using these data, we calculated approximate resistivities for the various geologic units (Table II). The water supply aquifer at Fenton Hill is buried under a thick (107 $\mathrm{m}$ at GT-2) layer of tuff and volcanic breccia. Because no water saturated zones were found in the overlying volcanics while drilling
GT-2, the aquifer, as a relatively conductive layer, was buried under a highly resistive overburden. In addition, because different volcanic strata have significantly different resistivities, we were also able to use $D C$ resistivity to map units in the overlying dry volcanics.

\section{RESULTS}

Figure 5 shows geoelectric section for all 19 Schlumberger sounding curves. We divided the data into four groups. Group $A$ includes all lines on an approximately $E-W$ line running along the top of Lake Fork Mesa, but terminating near the edge of San Antonio Canyon. Group B comprises those stations along a westward continuation of this line across San Antonio Creek valley. Group C includes three stations from the bottom of Lake Fork Canyon and Group $D$ includes four soundings on a generally north-south line on the mesa top between Rio Cebolla and San Antonio Creek.

Soundings taken on the western end of Lakefork Mesa (Group $A$ in Fig. 5) show a very 


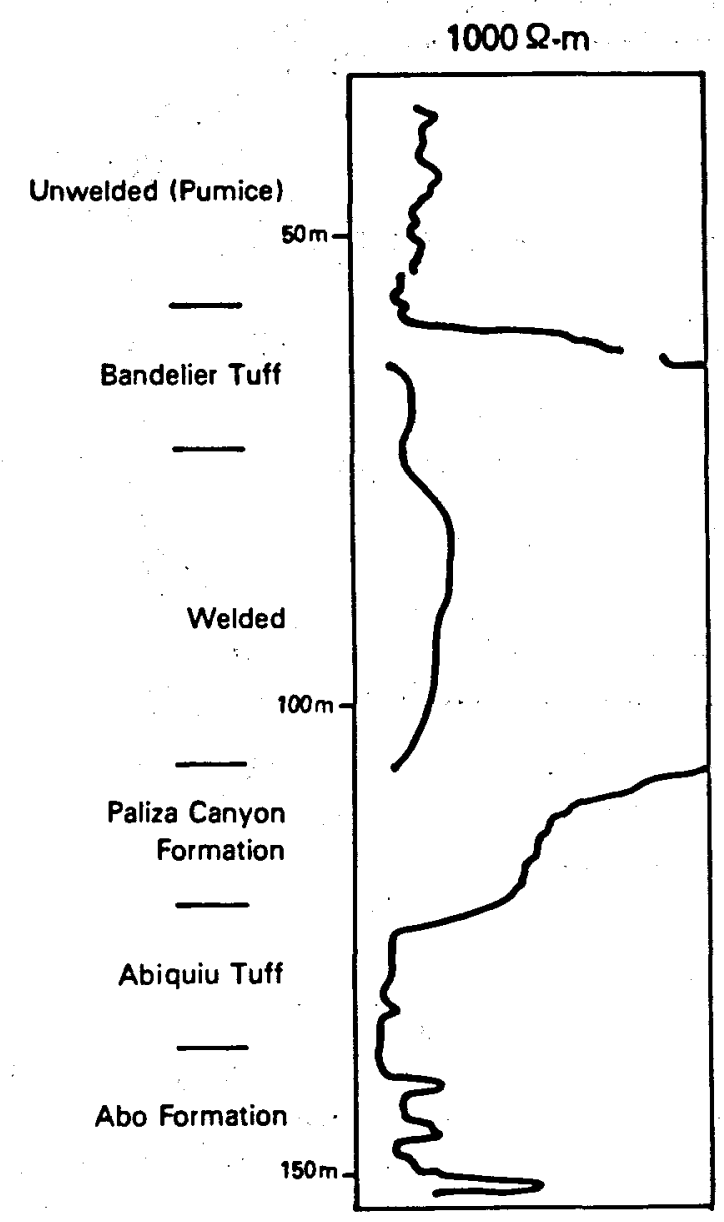

Fig. 4.

Purtymun, West, and Pettitt 5 correlated with a 16 normal resistivity log.

highly resistive layer that thins to the east. This layer pinches out near station TW-4 but apparently reappears near the drill site because we detect it again at TW-7. On the basis of the shallow GT-2 resistivity $\log$ (Fig. 4), we interpret this layer as a welded zone in the Bandelier Tuff. The intermediate resistivity zone (200$500 \mathrm{sm}$ ) is probably the Paliza Canyon Formation. The slight irregular boundary between the Bandelier Tuff and the Paliza Canyon Formation may indicate paleotopography covered by the Bandelier Tuff. flow. We could not differentiate between the Paliza Canyon formation and the upper unwelded parts of the Bandelier after the lower unwelded portion pinched out because the resistivity
Approximate Formation Resistivities

Formation

Res istivity

Range*

Unwel ded

240

Bandelier Tuff

Welded

$800-4800$

Bandelier Tuff

Paliza Canyon .

500

Formation

Abiquiu Tuff

80

(Saturated)

Abo Formation

$200-400$

*Estimated from 16 in. normal and 18.8 in. lateral electric logs corrected for borehole effects.

contrast was not large enough to be distinguishable using resistivity data alone. So, for the rest of the 1 ines, we interpreted intermediate resistivity rocks above the water table as undifferentiated volcanics.

The water table is apparently too deep to detect in the western end of line $A$. We first see it as a very low-resistivity layer at TW-4. The aquifer shallows to the northeast, a trend born out by all available Schlumberger lines except RE-8.

The soundings in Group B, which are in the bottom of San Antonio Canyon, all show fairly low resistivities throughout the geoelectric section. At RE-10, the low resistivities are probably caused by shale layers and perched water zones in the Abo Formation, which directly underlies this sounding. $R E-11,-12$ and -13 are in the flood plain of San Antonio Creek and the observed low resistivity there may be caused by saturated conditions to the surface.

Table. III is a summary of the resistivity and estimated depth to the top of the aquifer of 

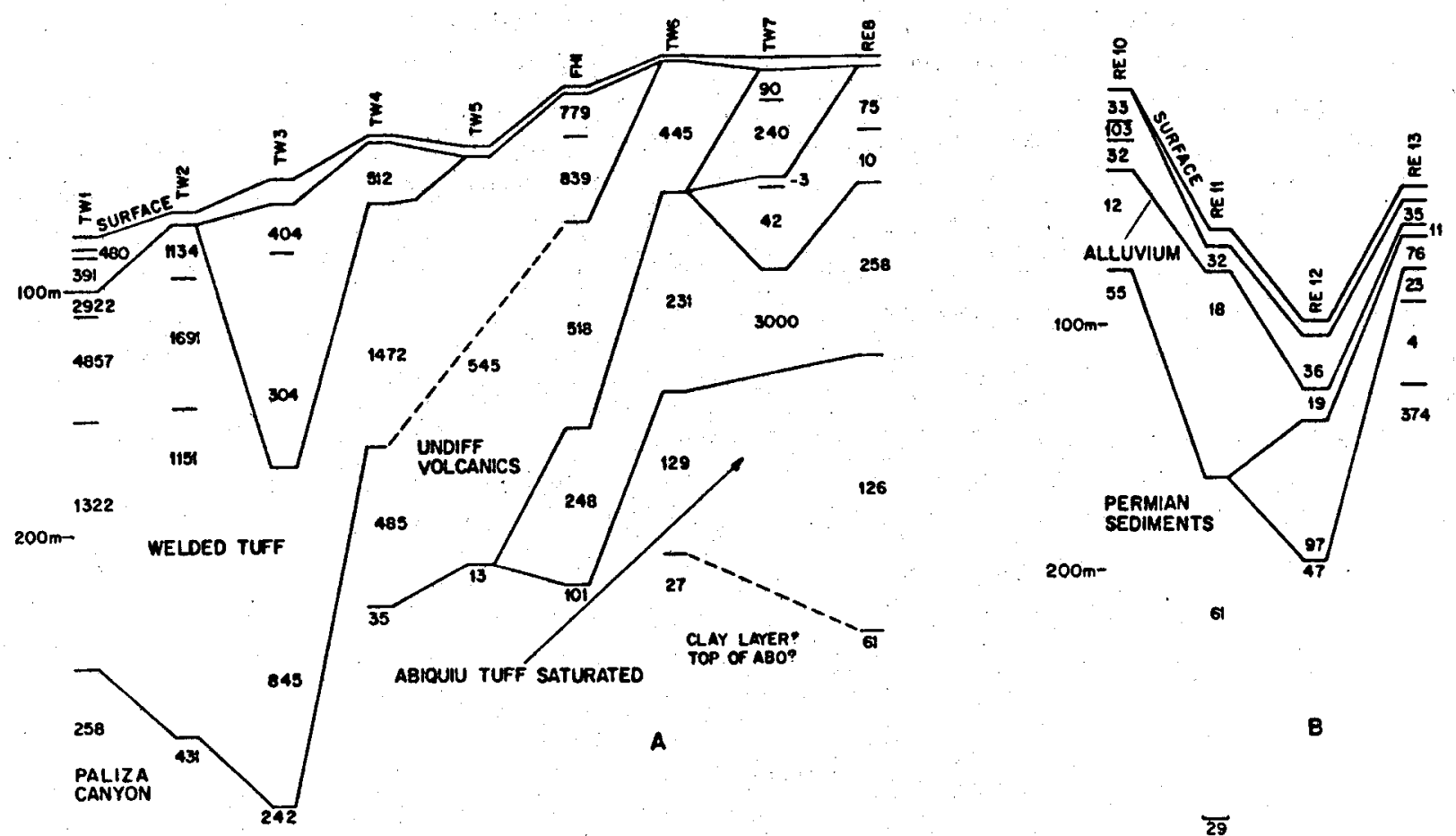

$\overline{29}$
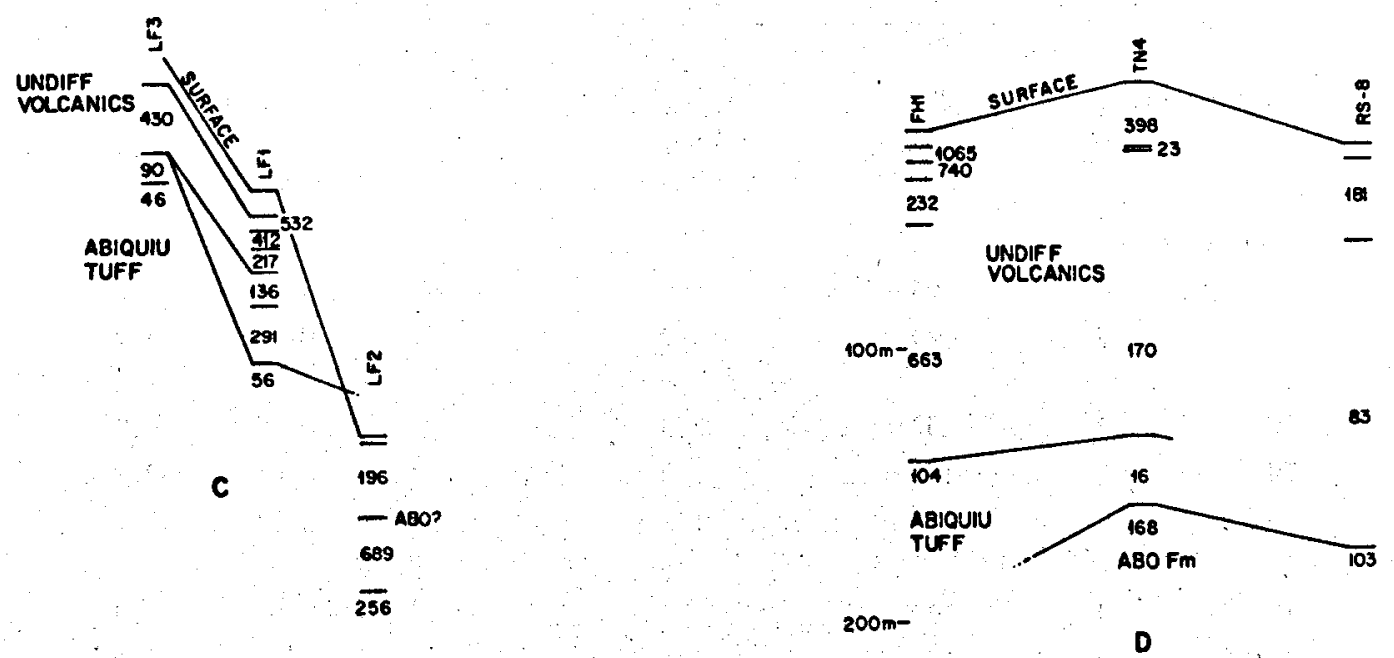

Fig. 5 .

Geoelectric sections from the Schlumberger soundings showing calculated formation resistivities in $\Omega-m$. 
nine soundings. The aquifer's formation resistivity is important because, for sands saturated with fresh water, the resistivity is related to the average grain size and eventually to the permeability of the reservoir.

The resistivity of brine saturated $s$ ands is described by Archie's ${ }^{9}$ well-known relationship where the formation resistivity is proportional to the water resistivity times the inverse square of the porosity. However, if the water resistivity is exceptionally high, as is always the case for aquifers supplying potable water, the formation resistivities may be several orders of magnitude greater than those predicted using Archie's equation. 10 This is because surface chemistry effects produce a thin, highly concentrated ionic film that controls the conductivity for rocks saturated with pure water where the natural ionic density. is low. Surface chemistry effects can become important if the water resistivity (Rw) is greater than $6 \Omega-m$, and they are certainly important for the Fenton Hill water supply aquifer, when $R w$ is approximately equal to 24 m. 11

The amount that surface conductance lowers the formation resistivity depends on the mean grain size because smal1. particles, with a higher ratio of surface area to volume, produce more surface film per unit volume than large particies. Alger et al.12 developed a log-linear relationship between the formation factor ( $R f$ divided by Rw) and the particle size that holds

TABLE III

RESISTIVITY AND POROSITIES SUMMARY

OF AQUIFER DEPTHS

\begin{tabular}{|c|c|c|c|c|c|c|}
\hline $\begin{array}{c}\text { Res istivity } \\
\text { Line }^{b}\end{array}$ & m Below & $\begin{array}{l}\text { Depth to } \\
\text { Surface }\end{array}$ & $\begin{array}{l}\text { Aquifer } \\
\text { m Below } 2652 \mathrm{~m} \\
\text { Datum Plane }\end{array}$ & $\underset{\Omega-m}{\text { Resistivity }}$ & $\begin{array}{l}\text { Mean } \\
\text { grain } \\
\text { size } \\
\mathrm{mm}\end{array}$ & $\begin{array}{l}\text { Permea- } \\
\text { bility } \\
\text { Darcies }\end{array}$ \\
\hline Fenton $\mathrm{Hill}$ & 1 & 202 & 217 & 104 & 0.30 & 27.4 \\
\hline & 2 & 121 & 121 & 104 & 0.30 & 27.4 \\
\hline Lake Fork & & & & & & \\
\hline Canyon & 1 & 64 & 204 & 56 & 0.15 & 7.1 \\
\hline & 3 & 46 & 137 & 49 & 0.13. & 4.9 \\
\hline TW & 4 & 192 & 229 & 35 & 0.02 & 0.8 \\
\hline TW & 5 & 165 & 208 & $13^{a}$ & $>0.01$ & $>0.3$ \\
\hline TW. & 6 & 136 & 142 & 129 & 0.14 & 37.1 \\
\hline TN & 4 & 132 & 124 & $16^{a}$ & $>0.01$ & $>0.3$ \\
\hline RE & 8 & 128 & 134 & 126 & 0.14 & 37.1 \\
\hline
\end{tabular}

aThis very low formation resistivity may well be caused by clay in the aquifer.

bee Fig. 1 for locations. 
for relatively pure waters ( $\mathrm{Rw}>5 \Omega-m)$, which can be used to predict the mean particle size from resistivity data. The mean particle size is important because permeability and grain size are related by a well-known empirical relationship and because large average grain sizes make ground water much easier to filter as it is produced. 13

We calculated mean grain sizes and permeabilities from the formation factor (F) using an empirical relationship found in the standard Schlumberger log interpretation charts. 14 . The results of these calculations, summarized in Table III, suggest that the aquifer permeability is highly variable, ranging from $<0.3$ darcies to 37 darcies. The mean grain size is also quite variable, ranging from $<0.003 \mathrm{~cm}$ east and north of Fenton $\mathrm{Hill}$ to nearly $0.04 \mathrm{~cm}$ near the drill site.

\section{INTERPRETATION}

Supporting an earlier interpretation by Purtymun, West, and Pettitt, ${ }^{6}$ our data suggest that the aquifer dips toward the southwest at a

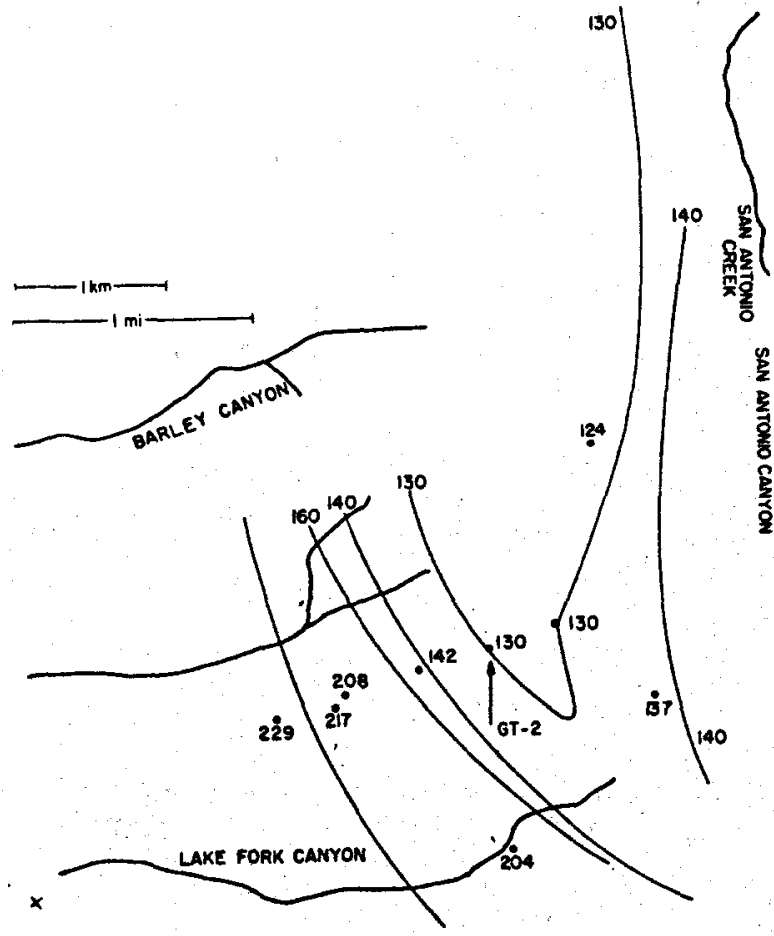

Fig. 6 .

Contours on the top of the aquifer near fenton $\mathrm{Hill}$ in $\mathrm{m}$. rate of $20-30 \mathrm{~m} / \mathrm{km}$. We also observed a sudden $60 \mathrm{~m}$ increase in the depth to the aquifer $1.5 \mathrm{~km}$ west of GT-2. This observation is illustrated in Fig. 6 where we have contoured the top of the aquifer using resistivity data. Kintzinger et al. 5 inferred a similar displacement in the top of the Abo formation from a high-resolution seismic reflection survey carried out slightly to the north of our survey area. This displacement may be related to the western boundary fault of a sharp north-south trending horst described by Kintzinger et al..$^{5}$ that passes approximately $1 \mathrm{~km}$ east of GT-2. Figure 7 shows a generalized isopach map of the dry volcanics that overlie the saturated portions of the Abiquiu Tuff. The slight increase in aquifer depth to the west indicated by LF-2 may be caused by the discharge of ground water at nearby Horseshoe Springs. Purtymun et al. ${ }^{6}$ suggest that the ground-water divide between San Antonio Creek Canyon and the Fenton Hill site occurs along a nearby north-south trending fautt. Aquifer resistivities, the mean

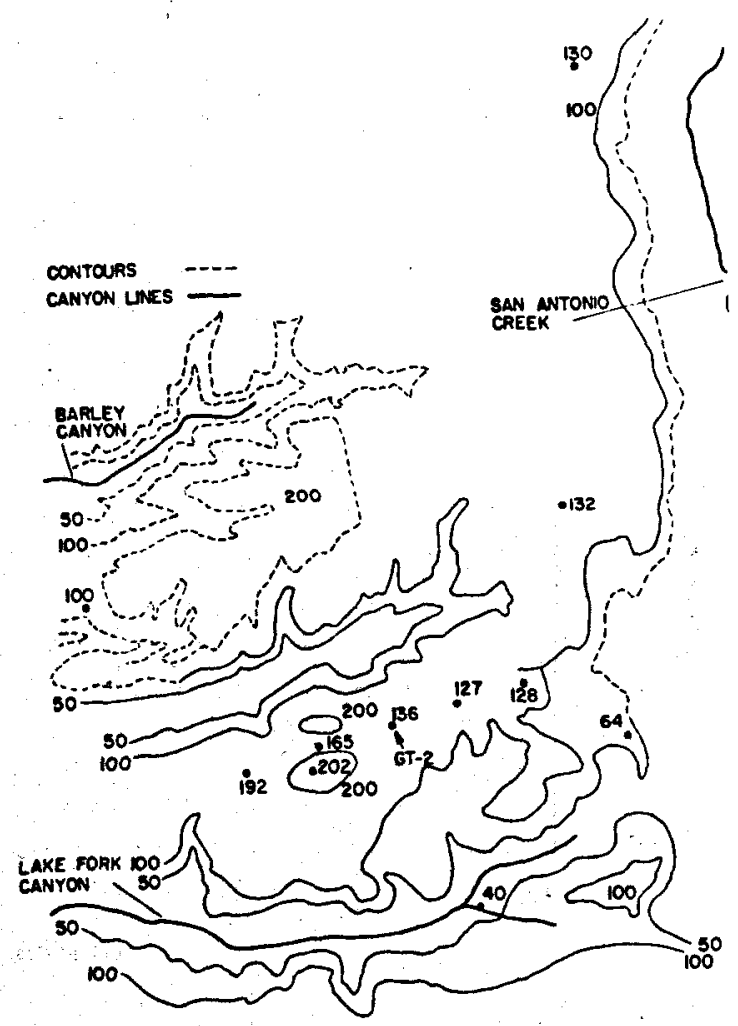

Fig. 7 .

Isopach map of the dry volcanics overlying the aquifer near Fenton $\mathrm{Hill}$. 
grain size, and the permeability all have their maximum values in the vicinity of the Fenton $\mathrm{Hill}$ site. Both permeability and grainsize decrease to the north, west; and south, al though the decline is quite erratic with mean particle sizes varying by as much as a factor of 6 within a few hundred meters. These sudden changes may be caused by variable amounts of clay in the aquifer.

\section{SENSITIVITY ANALYSIS}

We calculate the earth's resistivity by matching the observed VES curve with a curve calculated by assuming a particular distribution of resistivity with depth. However, because each resistivity measurement contains small errors, the calculated and observed curves will not match exactly and other slightly different resistivity models will satisfactorily, match our data. The sensitivity of the model to changing the resis- tivity or the depth of a layer is the minimum change that causes differences between the calculated and observed curves, which are greater than measurement error: Physically, the sensitivity is the minimum difference so that two models can be distinguished using resistivity data.

We estimated the sensitivity of our analys is to small changes in the water table's depth and thickness using a series of theoretical VES curves calculated for a simplified two-layer model of the aquifer. The first layer, representing the dry overburden, was $200 \mathrm{~m}$ thick with a $500 \Omega \mathrm{m}$ resistivity. The lower layer was infinitely thick, had a resistivity of $100 \Omega \mathrm{m}$, and represented the aquifer. We varied the depth and resistivity of the lower layer until there was a $10 \%$ change in the calculated VES curve, since $10 \%$ was our fitting tolerance to the observed VES curves. The variation in the resistivity or depth of the aquifer

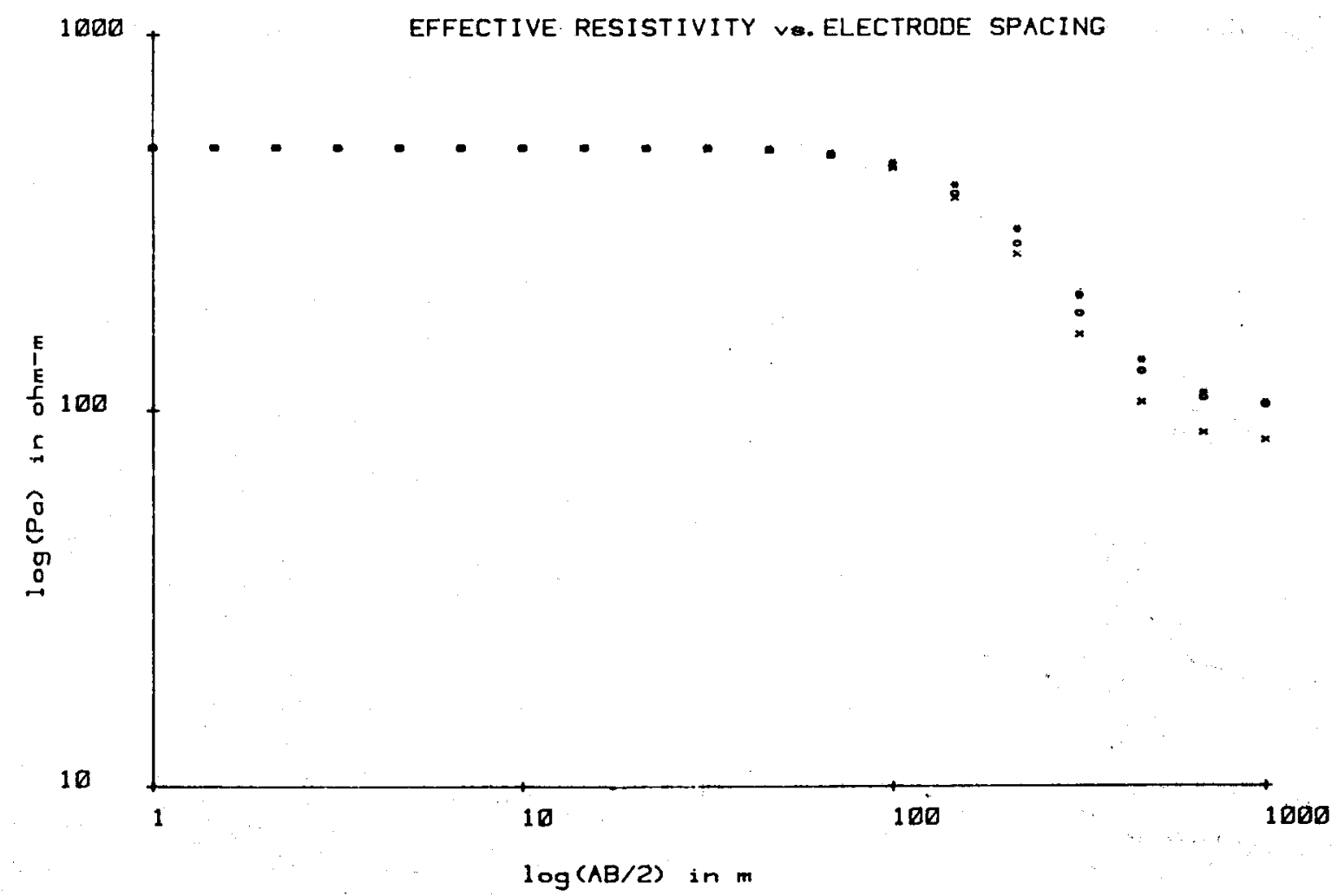

Fig. 8.

Synthetic Schlumberger VES curves showing the variation in the surface measurements attributable to small changes in the subsurface structure. 
represents the sensitivity of the model for this parameter. This analysis, as summarized in Fig. 8, suggests that we can distinguish changes of $10 \%$ or more in aquifer depth and $20 \%$ changes in aquifer resistivity.

\section{CONCLUSION}

There are two important conclusions from this study. (1) The aquifer dips gradually to the west near Fenton Hill. Depths below ground surface increase from $130 \mathrm{~m}$ near the Fenton Hill site to more than $200 \mathrm{~m} 4 \mathrm{~km}$ to the west, and depths below a $2652 \mathrm{~m}$ datum $\mathrm{plane}$ increase even more rapidly. Much of the elevation change occurs suddenly at $0.5 \mathrm{~km}$ west of Fenton Hill, possibly indicating an unmapped normal fault in the Permian sediments or topography in the prevolcanic surface. (2) The aquifer resistivity, and therefore the mean particle size and the permeability, are highest near Fenton Hill decreasing (somewhat unevenly) to the south and west. The erratic distribution of permeabilities near Fenton Hill may be caused by a variable clay or silt content in the aquifer. This suggests that any more water wells drilled into the Abiquiu Tuff should be preceded by detailed geoelectric surveys and only areas where the aquifer resistivity is relatively high $(>100 \Omega-m)$ should be considered as possible well sites.

\section{REFERENCES}

1. N. Becker, W. D. Purtymun, and W. Ballance, "Aquifer Evaluation at Fenton Hill, October-November, 1980," Los Alamos National Laboratory report LA-8964-MS (October 1981).

2. A. A. R. Zohdy, G, P. Eaton, and D. R. Mabey, "Applications of Surface Geophysics to Ground-Water Investigations in Techniques of Water-Resources Investigations of the United States," U. S. Geol. Surv., Chap. D-1 (1975).

3. G. J. Jiracek, "Deep Electrical Resistivity Investigations Coupled with Dry Geothermal" Reservoir Experiments in New Mexico," Univ. of New Mex. Tech. Program Report NSF-G1 42835, Univ. of New Mex., NM (1975):

4. R. L. Smith, R. A. Bailey, and C. S. Ross, "Geologic Map of the Jemez Mountains, New Mexico," Miscellaneous Geologic Investigations map 1-571, U. S. Geol. Surv. (1970).

5. P. R. Kintzinger, C. B. Reynolds, F. G. West, and G. Suhr, "Seismic Reflection Surveys near LASL Geothermal Site,": LoS Alamos Scientific Laboratory report LA-7228-MS (Apri) 1978).

6. W. D. Purtymun, F. G. West, and R. A. Pettitt, "Geology of Geothermal Test Hole GT-2 Fenton H11l Site, July 1974," Los Alamos Scientific Laboratory report LA-5780-MS (November 1974).
7. G. V. Keller and F. C. Frischnect, Electrical Methods in Geophysical Prospecting, Pergamon Press, New York, 95 pp (1966).

8. A. A. R. Zohdy, "Automatic Interpretation of Schlumberger Sounding Curves Using Modified DAR Zarrouk Functions," U. S. Geol. Surv. Bu11. 1313-E (1974).

9. C. E. Archie, "The Electrical Resistivity Log As An Aid in Determining Some Reservoir Characteristics", Trans. AIME 146 p 54-62, 1942.

10. E. I. Parkhomenko, Electrical Properties of Rocks, Plenum Press, Jew York, pp 277 (1967).

11. C. 0. Grigsby, "Well Water Analysis from Fenton Hill November 79-June 80," Los Alamos Scientific Laboratory internal document, November 11, 1980.

12. R. P. Alger, "Interpretation of Electric Logs in Fresh Water Wells in Unconsolidated Formations," Proceedings of the Society of Professional Well Log Analysts 27th Logging Symposium, May 8-11, 1966, Tulsa, Oklahoma.

13. United States Geological Survey Water Supply Paper 887, "Methods for Determining Permeability of Water Bearing Materials," pp 52 , 1942.

14. Schlumberger, "Log Interpretation Manual," Vol. II Applications, Schlumberger Ltd., New York, 29 pp (1974). 


\section{DESCRIPTION OF EQUIPMENT AND METHOD}

George Jiracek's 14 Schulmberger soundings were carried out using a commercially available Bison unit capable of producing a $25 \mathrm{~mA}$ maximum current. The electrical signal from this unit is an $11 \mathrm{~Hz}$ square wave. The voltage drop, also a square wave, is recorded on a portable strip chart recorder. The advantage of a square wave signal over a $D C$ current source is that the resulting voltage drop, recorded between the potential electrodes, appears as a square wave riding on top of any extraneous potentials due to telluric currents or contact potential. Because the signal. is the amplitude of the square wave, it can be measured without compensating for these extraneous potentials.

The 5 Schlumberger resistivity surveys that were carried out in the fall of 1980 were conducted with a Soil Test model $54 \mathrm{R}$ resistivity meter. This instrument consists of a $D C$ power supply capable of providing a $100 \mathrm{~mA}$ current at up to $650 \mathrm{~V}$, and a high impedance $D C$ voltmeter. In practice, poor battery and high contact resistance prevented us from reaching the maximum current. The voltmeter supplied with this unit contained a variable $D C$ offset that allowed us to buck out extraneous DC potentials by zeroing the meter before each reading. Whereas this procedure would not work if rapidly varying telluric currents are present, it was adequate for the purposes of this study, although rapidly varying potentials due to nearby lightning strikes occasionally forced us to suspend operations.

As is customary in DC resistivity surveys, we placed the current electrodes at logarithmically equispaced intervals, i.e., there were the same number of points between $1 \mathrm{~m}$ and $10 \mathrm{~m}$ as between $10 \mathrm{~m}$ and $100 \mathrm{~m}$, etc. Such spacing is desirable because the data are interpreted using log-log plots and logarithmics electrode spacing ensuring an even distribution of data over the curve. George Jiracek used 8 points per decade in his 14 Schlumberger soundings. During the five soundings carried out during the fall of 1980, we used 12 points per decade except for the first decade (from 1 to $10 \mathrm{~m}$ ) where we used 6 points. Electrode spacings used in both surveys are summarized in Table A-I. We surveyed the points using a $30 \mathrm{~m}$ tape and a Brunton compass to maintain constant bearing. Each point was marked with a labeled surveyor's stake. We calculated electrode spacings to three significant figures. Thus we measured the points to a precision of $0.01 \mathrm{~m}$ for spacings less than $10 \mathrm{~m}, 0.1 \mathrm{~m}$ for spacings between $10 \mathrm{~m}$ and $100 \mathrm{~m}$, and $1 \mathrm{~m}$ for spacings greater than $100 \mathrm{~m}$. In fact our measurement accuracy always exceeded these tolerances.

TABLE A-I

Used in Los Alamos

Used by Jiracek National Laboratory survey

$\begin{array}{lc}m & m \\ 1 & 2.15 \\ 1.33 & 3.16 \\ 1.78 & 4.64 \\ 2.37 & 6.82 \\ 3.16 & 10.0 \\ 4.22 & 12.1 \\ 5.62 & 14.6 \\ 7.50 & 17.8 \\ 10.0 & 21.5 \\ 13.3 & 26.1 \\ 17.8 & 31.6 \\ 23.7 & 38.3 \\ 31.6 & 46.4 \\ 42.2 & 56.2 \\ 56.2 & 68.2 \\ 75.0 & 82.5 \\ 100 & 100 \\ 133 & 121 \\ 18 & 146 \\ 237 & 178 \\ 16 & 215 \\ 500 & 261 \\ & 316 \\ & 383\end{array}$

2.15

4.64

6.82

10.0

2.1

4.6

17.8

21.5

26.1

31.6

8.3

56.2

68.2

82.5

46

178

215

383 
When conducting a Schlumberger sounding, we started by placing the current electrodes at the pair of stakes closest to the centerpoint. We placed the potential electrodes so that the spacing was less than $25 \%$ of the current electrode spacing $(A B)$. We then expanded the current electrode spacing after each measurement, leaving the potential electrodes fixed until the voltage became too small to read accurately. Then we sym- metrically expanded the potential electrodes using positions previously occupied by current electrodes to reduce surveying time. A survey ended when we could no longer measure a voltage drop greater than $5 \mathrm{mV}$ (below which reading errors exceeded $10 \%$ ) with expanding the potential electrodes beyond $25 \%$ of the current electrodes.

\section{APPENDIX B}

INTERPRETATIONS OF THE SCHLUMBERGER SOUNDING CURVES

$\begin{array}{ccccc}\Omega-m & m & m & \Omega-m & m \\ \text { Resistivity } & \text { Thickness } & \text { Depth } & \text { Resistivity } & \text { Thickness } \\ \text { Depth }\end{array}$

\begin{tabular}{|c|c|c|c|c|c|c|c|}
\hline TW-1 & $\begin{array}{r}1320 \\
921 \\
480 \\
391 \\
2922 \\
4857 \\
1322 \\
258\end{array}$ & $\begin{array}{r}0.3 \\
4.4 \\
3.1 \\
14.2 \\
9.6 \\
43.8 \\
100.5 \\
\infty\end{array}$ & $\begin{array}{r}0.3 \\
4.7 \\
7.8 \\
22.0 \\
31.6 \\
75.4 \\
175.9 \\
\infty\end{array}$ & TW-6 & $\begin{array}{r}206 \\
445 \\
231 \\
129 \\
27\end{array}$ & $\begin{array}{c}1.7 \\
53.0 \\
81.2 \\
66.2 \\
\infty\end{array}$ & $\begin{array}{r}1.7 \\
54.8 \\
135.9 \\
202.1 \\
\infty\end{array}$ \\
\hline TW-2 & $\begin{array}{r}1049 \\
307 \\
209 \\
1134 \\
1691 \\
1151\end{array}$ & $\begin{array}{r}0.8 \\
0.6 \\
3.8 \\
21.6 \\
51.5 \\
135.9\end{array}$ & $\begin{array}{r}0.8 \\
1.4 \\
5.2 \\
26.8 \\
78.3 \\
214.2\end{array}$ & & & & \\
\hline & 431 & $\infty$ & $\alpha$ & TN -4 & $\begin{array}{r}683 \\
367 \\
3151\end{array}$ & $\begin{array}{l}0.6 \\
1.6 \\
0.6\end{array}$ & $\begin{array}{l}0.6 \\
2.2 \\
2.8\end{array}$ \\
\hline$T W-3$ & $\begin{array}{r}1585 \\
657 \\
266 \\
738 \\
404 \\
304 \\
845\end{array}$ & $\begin{array}{r}0.5 \\
0.4 \\
0.5 \\
8.2 \\
21.0 \\
86.1 \\
141.9\end{array}$ & $\begin{array}{r}0.5 \\
0.9 \\
1.4 \\
9.5 \\
30.5 \\
116.6 \\
258.5\end{array}$ & & $\begin{array}{r}398 \\
23 \\
170 \\
16 \\
168\end{array}$ & $\begin{array}{r}22.8 \\
3.0 \\
103.3 \\
26.0 \\
\infty\end{array}$ & $\begin{array}{r}25.6 \\
28.5 \\
131.8 \\
157.9 \\
\infty\end{array}$ \\
\hline & 242 & $\infty$ & $\infty$ & LF -1 & $\begin{array}{r}261 \\
2371 \\
864\end{array}$ & $\begin{array}{l}3.2 \\
0.5 \\
1.9\end{array}$ & $\begin{array}{l}3.2 \\
3.7 \\
5.6\end{array}$ \\
\hline$T W-4$ & $\begin{array}{r}227 \\
133 \\
512 \\
1472 \\
485 \\
35\end{array}$ & $\begin{array}{r}0.6 \\
2.2 \\
15.5 \\
109.1 \\
64.3 \\
\infty\end{array}$ & $\begin{array}{r}0.6 \\
2.8 \\
18.3 \\
127.4 \\
191.7 \\
\infty\end{array}$ & & $\begin{array}{r}644 \\
532 \\
412 \\
217 \\
136 \\
291 \\
56\end{array}$ & $\begin{array}{c}3.2 \\
4.8 \\
6.9 \\
9.0 \\
12.3 \\
22.3 \\
\infty\end{array}$ & $\begin{array}{c}8.8 \\
13.6 \\
20.6 \\
29.6 \\
41.9 \\
64.2 \\
\infty\end{array}$ \\
\hline$T W-5$ & $\begin{array}{r}295 \\
40 \\
545 \\
13\end{array}$ & $\begin{array}{r}1.0 \\
0.8 \\
163.0 \\
\infty\end{array}$ & $\begin{array}{r}1.0 \\
1.8 \\
164.8 \\
\infty\end{array}$ & $L F-3$ & $\begin{array}{r}1162 \\
347 \\
185 \\
430 \\
90 \\
49\end{array}$ & $\begin{array}{r}5.4 \\
1.9 \\
2.2 \\
25.3 \\
11.0 \\
\infty\end{array}$ & $\begin{array}{r}5.4 \\
7.4 \\
9.5 \\
34.9 \\
45.8 \\
\infty\end{array}$ \\
\hline
\end{tabular}


APPENOIX B (CONTINUED)

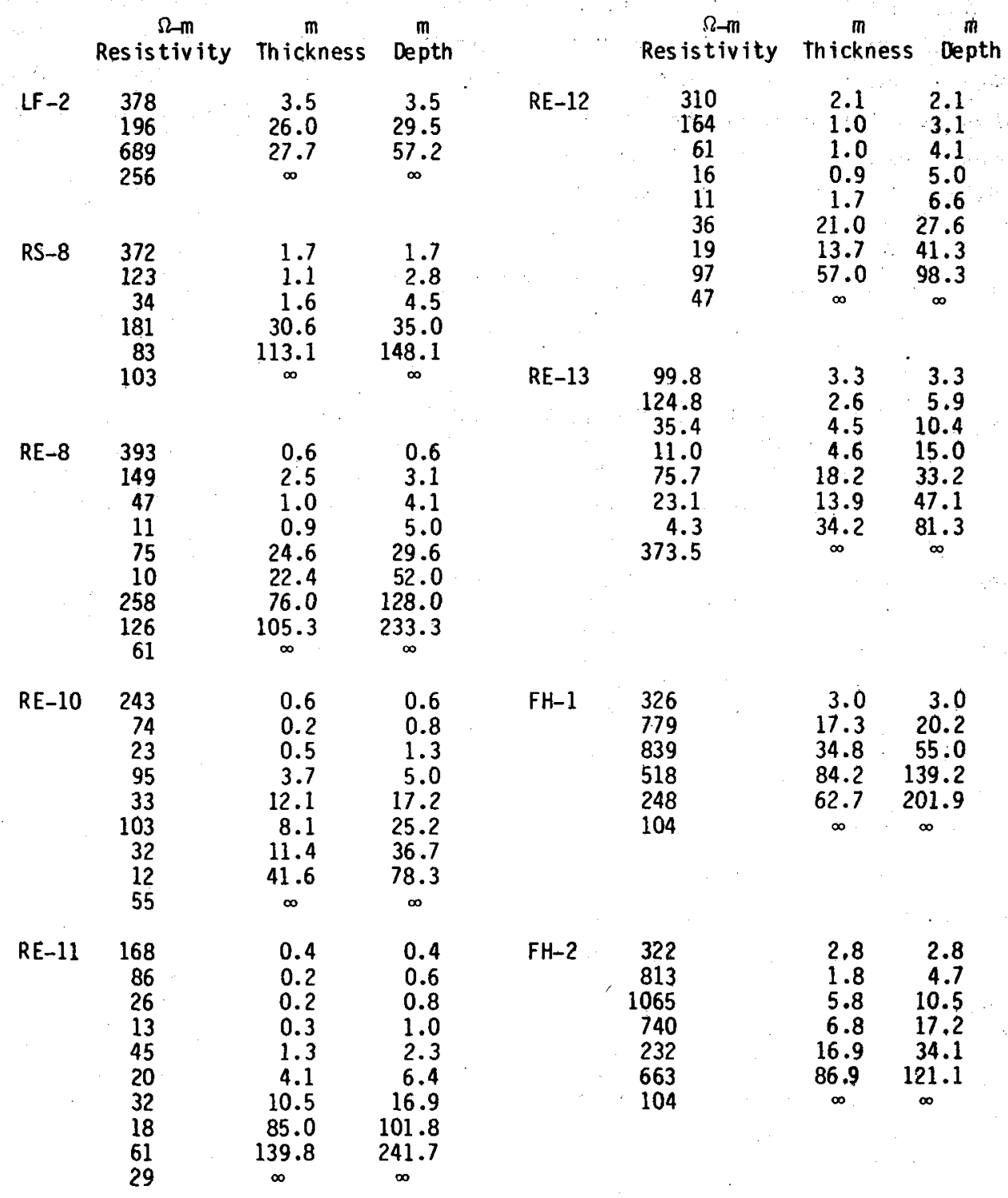


APPENDIX $C$

APPARENT RESISTIVITY (PU) VS ELECTRODE SPACING (AB/2) CURVES

FOR THE 19 SCHLUMBERGER SOUNDINGS
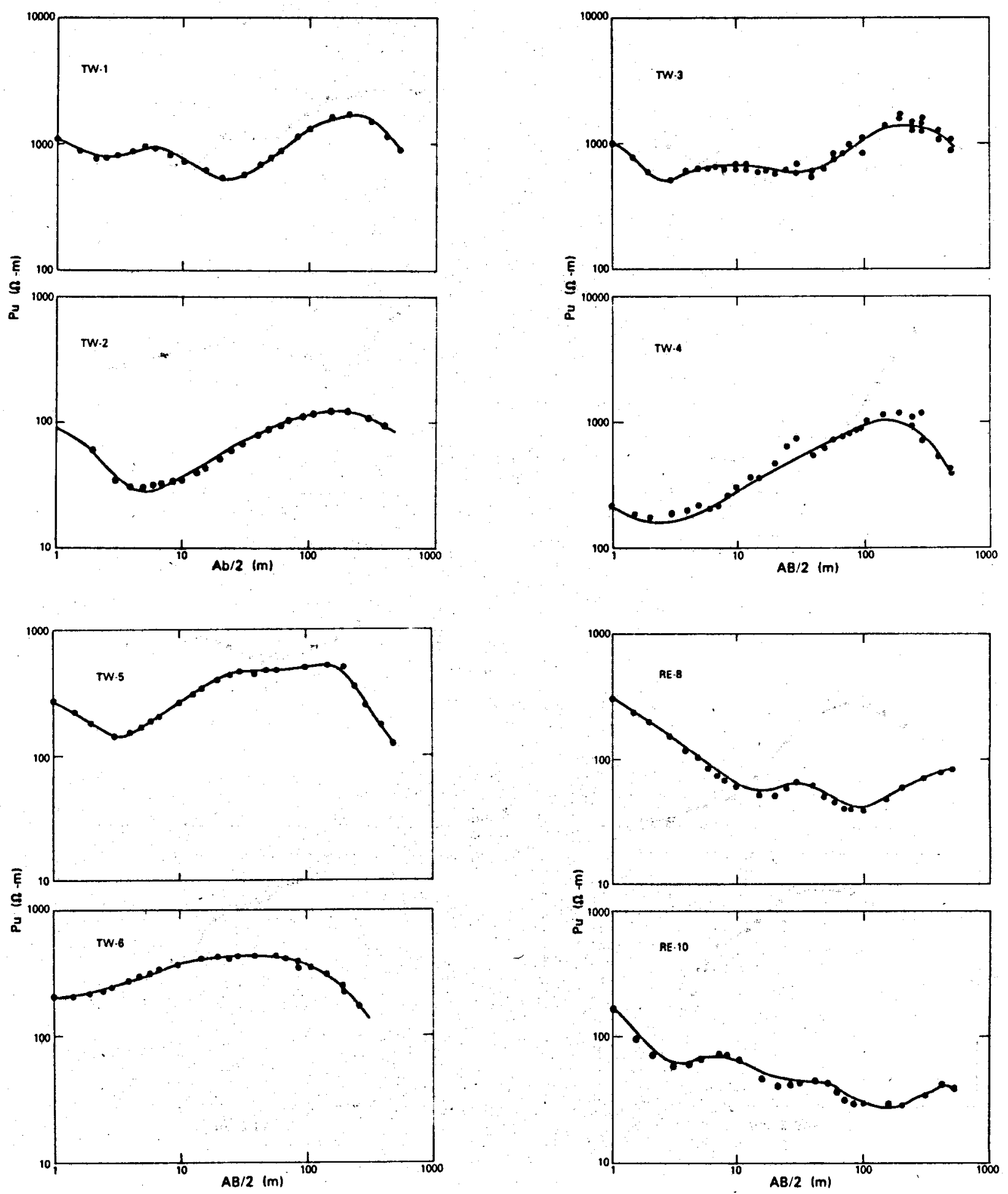

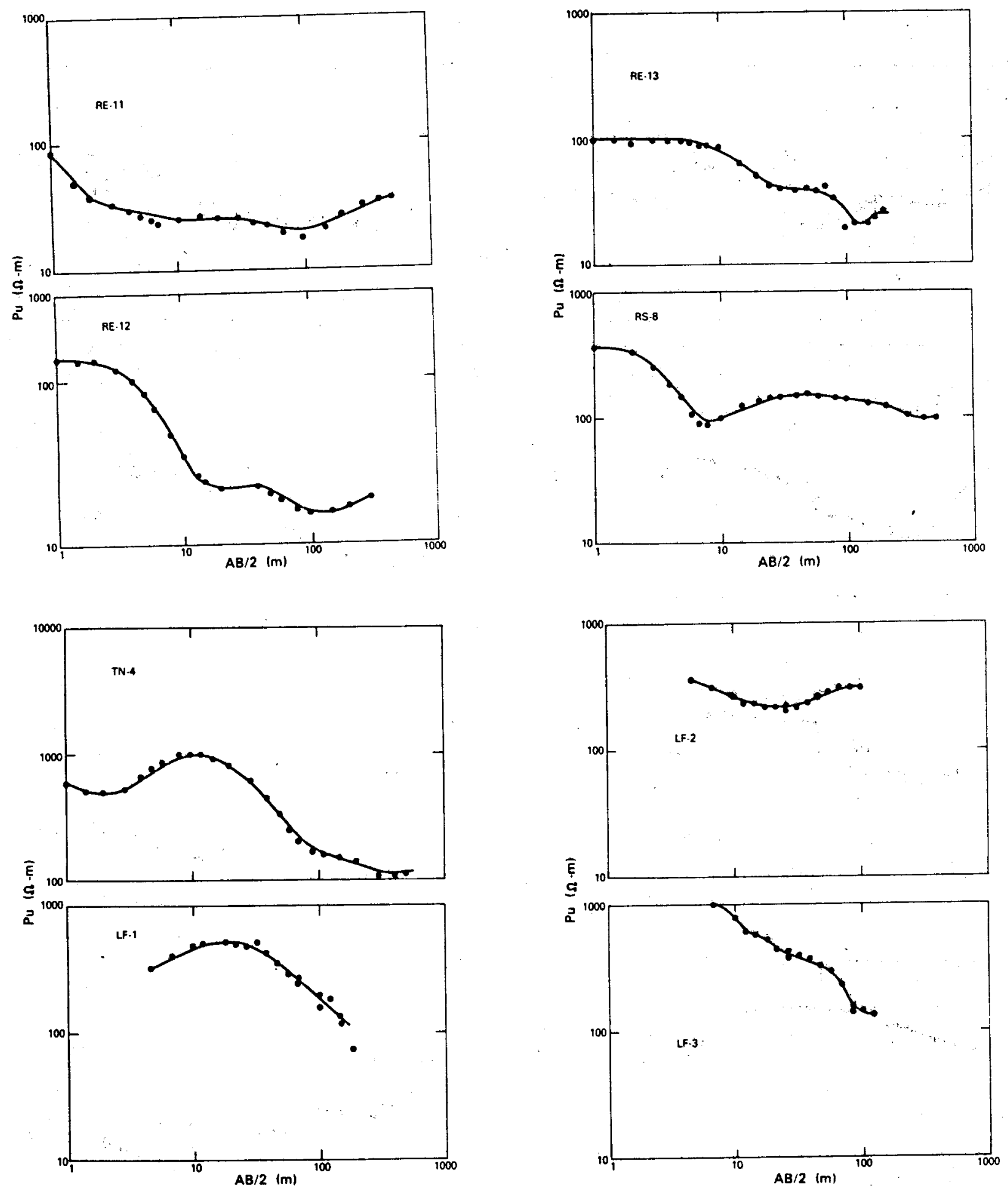
APPENDIX C (CONTINUED)
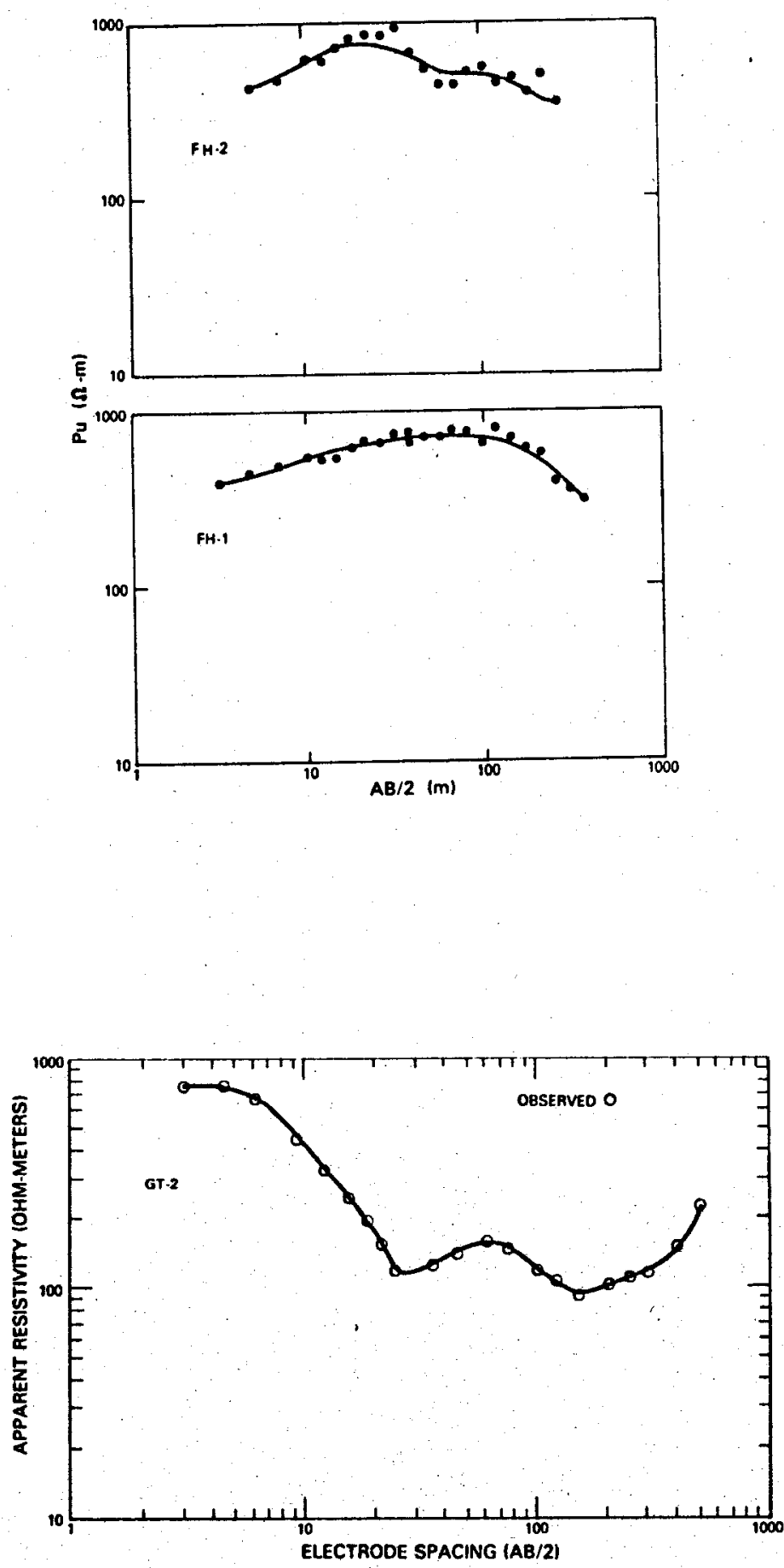


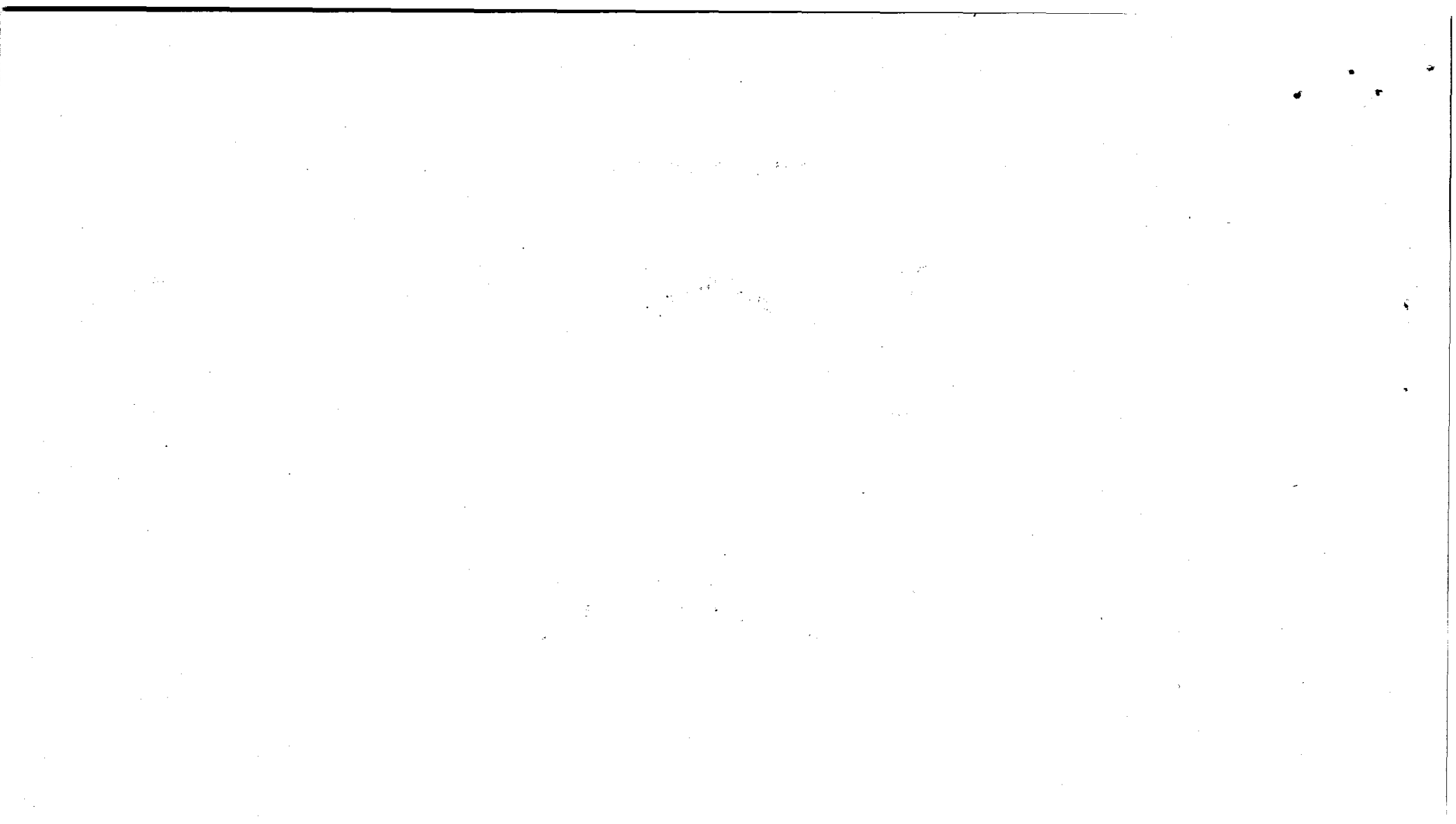

